\title{
Low pH in simulated acid rain promotes the toxicity of copper on the physiological performance in Sargassum horneri
}

\author{
Z.H. ZHONG ${ }^{*}$, S. QIN*, Y. WANG ${ }^{*, * *}$, C. MA*,***, and Z.Y. LIU ${ }^{*,+}$ \\ Yantai Institute of Coastal Zone Research, Chinese Academy of Sciences, 264003 Yantai, China* \\ Hohai University, Nanjing, 210098 Jiangsu, China** \\ Shanxi Agricultural University, Jinzhong, 030801 Shanxi, China***
}

\begin{abstract}
In order to investigate the interactive effects of simulated acid rain and copper $(\mathrm{Cu})$ on macroalgae, Sargassum horneri was cultured under $\mathrm{pH}$ of $8.2,5.6,4.5$ and $\mathrm{Cu}$ concentrations of $0,25,100 \mu \mathrm{g} \mathrm{L}^{-1}$. Under the medium concentration of $\mathrm{Cu}$, moderate $\mathrm{pH}$ mitigated the toxicity of $\mathrm{Cu}$ on $\mathrm{S}$. horneri, while the low $\mathrm{pH}$ and high $\mathrm{Cu}$ concentration reduced the contents of chlorophyll (Chl) $a$ and carotenoids. Furthermore, $\mathrm{pH}$ had no interaction with $\mathrm{Cu}$ on maximal Chl fluorescence or electron transport efficiency, while effective PSII quantum yield, maximum electron transport rate, and saturating irradiance were obviously affected by $\mathrm{pH}$ and $\mathrm{Cu}$, and the interactive effects were significant. Additionally, with the increasing $\mathrm{Cu}$ concentration and decreasing $\mathrm{pH}$, nonphotochemical quenching and regulated energy dissipation dropped sharply, while nonregulated energy dissipation increased. Therefore, the high concentration of $\mathrm{Cu}$ and low $\mathrm{pH}$ had synergistic effects on the photosynthetic performance and growth of $S$. horneri.
\end{abstract}

Additional key words: environmental problem; metal pollution; photoprotective ability; photosynthetic apparatus; Sargassum beds.

\section{Introduction}

Acid rain and heavy metal pollution have become serious environmental problems around the world in recent decades. Acid rain is caused mainly by sulfur dioxide $\left(\mathrm{SO}_{2}\right)$ and nitrogen oxides $\left(\mathrm{NO}_{\mathrm{x}}\right)$ emission, and the $\mathrm{pH}$ of acid rain is usually lower than 5.6 (Li et al. 2017, Wang et al. 2018). China has become one of the severely acid-rain polluted countries, especially in the southern and southwestern parts (Ma et al. 2019). In Zhejiang Province, acid rain is a serious problem in Ningbo, Jinhua, and Wenzhou, and $\mathrm{pH}$ of the acid rain was as low as 3.24 (Gao et al. 2016, Li et al. 2017). It has already been proven that acid rain is harmful to plants ( $\mathrm{Li}$ et al. 2017). The gene expression could be damaged by acid rain directly or indirectly (Du et al. 2017). In addition, the growth, photosynthetic abilities, seedling emergence, and biodiversity declined with the frequency of strong acid rain (Shukla et al. 2013, Gao et al. 2016)

In addition, heavy metal pollution is mainly caused by anthropogenic activities, including burning garbage, industrial waste, overuse of chemical fertilizer and pesti- cide; it threatens the environmental ecosystem (Flemming and Trevors 1989, Giordani et al. 2005). Furthermore, heavy metal pollution is one of the common contaminants in an estuarine or coastal zone (Milan et al. 2016, Gao et al. 2017). The concentration of $\mathrm{Cu}^{2+}$ in offshore marine environments in China is reportedly from 0.1 to $43.2 \mu \mathrm{g} \mathrm{L}^{-1}$ (Jin et al. 2015). $\mathrm{Cu}$ is one of essential micronutrients for growth and development of plant (Zou et al. 2015), which is necessary for photosynthesis and respiration and it is required for electron transport proteins (Raven et al. 1999). However, when $\mathrm{Cu}$ concentration is excessive, it inhibits the growth, photosynthetic activity, photosynthetic pigment synthesis, and enzyme activities of algae (Brown and Newman 2003, Lombardi and Maldonado 2011, Rocha et al. 2016). Therefore, acid rain and copper pollution are harmful to the growth and development of plants. However, previous studies focused on the higher plants (Gong et al. 2019, Liu et al. 2019, Ma et al. 2019). Less effort has been devoted to the interactive effects of acid rain and copper pollution on marine organisms, especially on macroalgae.

Sargassum horneri (Turner) C. Agardh widely distri-

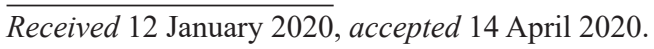

${ }^{+}$Corresponding author; e-mail: zyliu@yic.ac.cn

Abbreviations: $\mathrm{Car}$ - carotenoids; $\mathrm{Chl}$ - chlorophyll; $\mathrm{F}_{0}$ - minimal fluorescence yield of the dark-adapted state; $\mathrm{F}_{\mathrm{m}}$ - maximal fluorescence yield of the dark-adapted state; $\mathrm{F}_{\mathrm{m}}{ }^{\prime}$ - maximal fluorescence yield of the light-adapted state; $\mathrm{F}_{\mathrm{s}}$ - steady-state fluorescence yield; $\mathrm{F}_{\mathrm{v}}$ - variable fluorescence; $\mathrm{F}_{\mathrm{v}} / \mathrm{F}_{\mathrm{m}}$ - maximum PSII quantum yield; $I_{\mathrm{k}}$ - saturated irradiance; NPQ - nonphotochemical quenching; rETR - relative electron transfer rate; $\mathrm{rETR}_{\max }$ - maximum electron transport rate; $\mathrm{RGR}$ - relative growth rate; $\mathrm{Y}_{\text {(II) }}$ - actual photochemical efficiency of PSII; $\mathrm{Y}_{(\mathrm{NO})}$ - quantum yield of nonregulated energy dissipation; $\mathrm{Y}_{(\mathrm{NPQ})}$ - quantum yield of regulated energy dissipation; $\alpha$-electron transport efficiency.

Acknowledgements: This work was supported by Technology Innovation Development Program of Yantai (2020MSGY058), the National Key R\&D Program of China (2017YFC0506200), Shandong Province Science Foundation for Youths (ZR201807120023), Key Research and Development Program of Yantai (2018ZHGY082). 
butes on rocks from lower intertidal to subtidal zones along the coastline of the northern Pacific (Komatsu et al. 2014, Xu et al. 2018) (Fig. 1). This brown seaweed is an important contributor to the primary production in coastal zones for forming up Sargassum beds, an important marine ecosystem for providing spawning, nursing, and feeding for other marine organisms (Miki et al. 2016, Xu et al. 2017). The fast-growing $S$. horneri is usually chosen to construct Sargassum beds in Japan and Korea (Uji et al. 2016). Unfortunately, in recent years, Sargassum beds have degenerated rapidly in the world (Miki et al. 2016). The Nanji Island, Zhejiang Province, China $\left(27^{\circ} 27^{\prime} 7 \mathrm{~N}\right.$, $121^{\circ} 05^{\prime} 5 \mathrm{E}$ ) was once a place of rich $S$. horneri; however, Sargassum beds have declined in vast areas in recent decades, which was caused mainly by environmental changes in the factors including the elevated sea water temperature, and land reclamation (Komatsu et al. 2014). In addition, acid rain might also pose a threat on Sargassum beds as it frequently occurred in Zhejiang Province, China. Besides, the physiology of $S$. horneri could be harmed when exposed to high $\mathrm{Cu}$ concentration. Therefore, in this study, the impacts of acid rain and $\mathrm{Cu}$ pollution on the physiological characteristics of $S$. horneri were analyzed to find the reasons of the degradation and to provide supports for saving and remedying the Sargassum beds.

\section{Materials and methods}

Plants and culture conditions: $S$. horneri was sampled in March 2019 from Gouqi Island, Zhejiang Province $\left(30^{\circ} 42^{\prime} \mathrm{N}, 122^{\circ} 48^{\prime} \mathrm{E}\right)$ (Fig. 1). The thalli were cleaned on site directly, and delivered to laboratory in cooler box by airplane within $48 \mathrm{~h}$. After arrival at laboratory, the thalli were rinsed gently with filtered seawater at least three times to remove epiphytes, sediments, and other grazers. Afterwards, they were cultured in enriched natural seawater (the concentration of $\mathrm{NaNO}_{3}$ and $\mathrm{NaPO}_{4} \cdot 12 \mathrm{H}_{2} \mathrm{O}$ was $100 \mu \mathrm{M}$ and $10 \mu \mathrm{M}$, respectively). The precultural conditions set temperature of $16 \pm 1^{\circ} \mathrm{C}$, light intensity of $100 \mu \mathrm{mol}$ (photon) $\mathrm{m}^{-2} \mathrm{~s}^{-1}$, and salinity of $30 \%$, with a light/ dark period of $12 / 12 \mathrm{~h}$, and constant aeration with ambient air. After being incubated for $7 \mathrm{~d}$, the lateral branch of $S$. horneri was cut off for the experiment.

Experimental design: Approximately $0.5 \mathrm{~g}$ of thalli fresh mass (FM) were placed in 1-L flasks and cultured at crossed three concentrations of $\mathrm{Cu}[0,25$, and $100 \mu \mathrm{g}(\mathrm{Cu})$ $\left.\mathrm{L}^{-1}\right]$ and three $\mathrm{pH}$ levels $(4.5,5.6$, and 8.2$)$ for $7 \mathrm{~d}$.

\begin{tabular}{ll}
\hline Cu concentration $\left[\mu \mathrm{g} \mathrm{L}^{-1}\right]$ & $\mathrm{pH}$ level \\
\hline 0 & 4.5 \\
& 5.6 \\
& 8.2 \\
25 & 4.5 \\
& 5.6 \\
& 8.2 \\
100 & 4.5 \\
& 5.6 \\
& 8.2 \\
\hline
\end{tabular}

The medium was made from natural seawater with addition of $100 \mu \mathrm{M} \mathrm{NaNO}_{3}$ and $10 \mu \mathrm{M} \mathrm{NaPO}_{4} \cdot 12 \mathrm{H}_{2} \mathrm{O}$, and the concentration of $\mathrm{Cu}$ in natural seawater was $1.28 \mu \mathrm{g} \mathrm{L}^{-1}$, the $\mathrm{Cu}$ concentration in treatments was measured by an atomic absorption spectrophotometer (AA240, Varian, USA). The $\mathrm{pH}$ levels were made by the mixed acid solution [mix of $\mathrm{H}_{2} \mathrm{SO}_{4}(1 \mathrm{M})$ and $\mathrm{HNO}_{3}(1 \mathrm{M})$ in a $2: 1$ ratio $(\mathrm{Li}$ et al. 2017)]. The cultural conditions were set at temperature of $20^{\circ} \mathrm{C}$, light intensity of $100 \mu \mathrm{mol}$ (photon) $\mathrm{m}^{-2} \mathrm{~s}^{-1}$, and salinity of $30 \%$, with the light/dark period of $12 / 12 \mathrm{~h}$ and continuous aeration with ambient air. After $7 \mathrm{~d}$, the growth and physiological responses of $S$. horneri were determined.

Relative growth rate (RGR): The RGR was calculated as follows: $\mathrm{RGR}=100 \times \ln \left(\mathrm{W}_{\mathrm{t}} / \mathrm{W}_{0}\right) / \mathrm{t}$, where $\mathrm{W}_{0}$ is the initial $\mathrm{FM}$ and $\mathrm{W}_{\mathrm{t}}$ is the final FM after $\mathrm{t}$ days. Before weighting the algae, samples were softly blotted using filter paper to remove excess water.

Chlorophyll (Chl) $\boldsymbol{a}$ and carotenoid (Car) content: Approximately $0.01 \mathrm{~g}$ of FM of $S$. horneri were ground in methanol $(3 \mathrm{~mL})$ with quartz sand, then the volume was fixed to $10 \mathrm{~mL}$ with methanol and placed in darkness for $24 \mathrm{~h}$ at $4^{\circ} \mathrm{C}$. Afterwards, the samples were centrifuged for $10 \mathrm{~min}$ at $5,000 \mathrm{rpm}$ at $4^{\circ} \mathrm{C}$, then the absorbance values of the sample were obtained by a scanning spectrophotometer (UV6100A, Yuanxi Instrument Co., Ltd., China), and the contents of pigments were determined according to Porra (2002) and Parsons and Strickland (1963): Chl $a\left[\mu \mathrm{g} \mathrm{mL}^{-1}\right]=$ $16.29 \times\left(\mathrm{A}_{665}-\mathrm{A}_{750}\right)-8.54 \times\left(\mathrm{A}_{652}-\mathrm{A}_{750}\right), \operatorname{Car}\left[\mu \mathrm{g} \mathrm{mL} \mathrm{m}^{-1}\right]=$ $7.6 \times\left[\left(\mathrm{A}_{480}-\mathrm{A}_{750}\right)-1.49 \times\left(\mathrm{A}_{510}-\mathrm{A}_{750}\right)\right]$.

In vivo Chl fluorescence: Chl fluorescence parameter of PSII of $S$. horneri was measured with a pulse amplitude modulated fluorometer (Diving-PAM, Walz, Germany). The actinic light was set as $104 \mu \mathrm{mol}$ (photon) $\mathrm{m}^{-2} \mathrm{~s}^{-1}$, which was approximately consistent with the culture light intensity, and the saturating pulse was 5,640 $\mu \mathrm{mol}$ (photon) $\mathrm{m}^{-2} \mathrm{~s}^{-1}$. After 15-min dark adaption, the minimal fluorescence level $\left(\mathrm{F}_{0}\right)$ was measured with measuring light at the low frequency, the maximal fluorescence $\left(\mathrm{F}_{\mathrm{m}}\right)$ was obtained

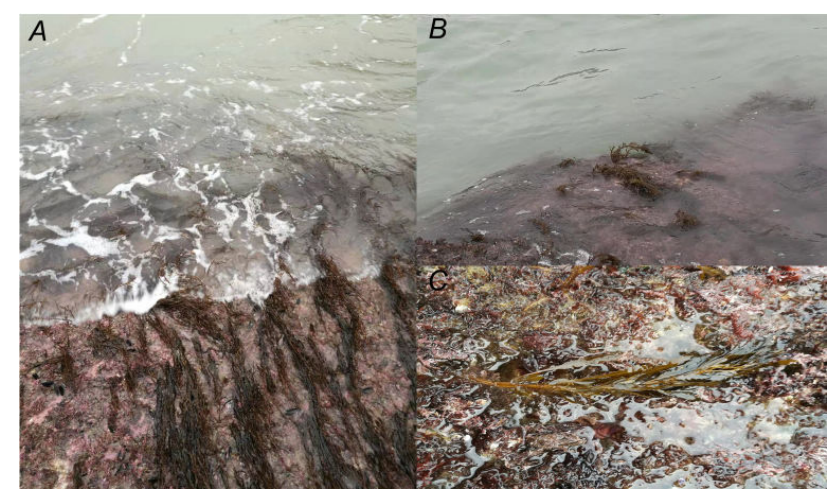

Fig. 1. Sargassum horneri in the intertidal zone of Gouqi Island, Zhejiang Province during low tides. 
by applying a saturating pulse, the maximal fluorescence level $\left(\mathrm{F}_{\mathrm{m}}{ }^{\prime}\right)$ was determined by applying a saturating pulse of actinic light $\left[104 \mu \mathrm{mol}\right.$ (photon) $\mathrm{m}^{-2} \mathrm{~s}^{-1}$ ], and the Chl fluorescence yield $\left(\mathrm{F}_{\mathrm{s}}\right)$ was obtained during the actinic irradiance. The following parameters were calculated based on the studies of Belshe et al. (2007) and Wang et al. (2009): (1) maximum PSII quantum yield, $\mathrm{F}_{\mathrm{v}} / \mathrm{F}_{\mathrm{m}}=$ $\left(\mathrm{F}_{\mathrm{m}}-\mathrm{F}_{0}\right) / \mathrm{F}_{\mathrm{m}} ;(2)$ effective quantum yield of PSII, $\mathrm{Y}_{(\mathrm{II})}=$ $\mathrm{F}_{\mathrm{v}}{ }^{\prime} / \mathrm{F}_{\mathrm{m}}{ }^{\prime}=\left(\mathrm{F}_{\mathrm{m}}{ }^{\prime}-\mathrm{F}_{\mathrm{s}}\right) / \mathrm{F}_{\mathrm{m}}{ }^{\prime} ;$ (3) nonphotochemical quenching, $\mathrm{NPQ}=\left(\mathrm{F}_{\mathrm{m}} / \mathrm{F}_{\mathrm{m}}{ }^{\prime}\right)-1 ;(4)$ quantum yield of regulated energy dissipation, $\mathrm{Y}_{(\mathrm{NPQ})}=\mathrm{F}_{\mathrm{s}} / \mathrm{F}_{\mathrm{m}}{ }^{\prime}-\mathrm{F}_{\mathrm{s}} / \mathrm{F}_{\mathrm{m}}$; (5) quantum yield of nonregulated energy dissipation, $\mathrm{Y}_{(\mathrm{NO})}=\mathrm{F}_{\mathrm{s}} / \mathrm{F}_{\mathrm{m}}$.

The rapid light curves (RLCs) can be obtained by a series of 20-s light exposures with increasing irradiance [0, 38, 104, 186, 322, 463, 621, 893; and 1,189 $\mu$ mol(photon) $\mathrm{m}^{-2} \mathrm{~s}^{-1}$. Relative electron transfer rate, $\mathrm{rETR}=\mathrm{F}_{\mathrm{v}}{ }^{\prime} / \mathrm{F}_{\mathrm{m}}{ }^{\prime} \times$ $\mathrm{AF} \times \mathrm{PAR} \times 0.5$, where AF is the light absorption capacity, and PAR is the actinic photosynthetically active radiation. The parameters of the RLCs were calculated following the rETR curves following the models (Eilers and Peeters 1988):

$\mathrm{rETR}=I /\left(a I^{2}+b I+c\right)$,

$I_{\mathrm{k}}=(c / a)^{1 / 2}, \alpha=1 / c$,

$\mathrm{rETR}_{\max }=1 /\left[b+2(a c)^{1 / 2}\right]$ where $\mathrm{rETR}_{\max }$ is the maximum electron transport rate, $\alpha$ is the electron transport efficiency, $I$ is the incident irradiance, $I_{\mathrm{k}}$ is the saturated irradiance, and $a, b$, and $c$ are the adjustment parameters.

Statistical analyses: Significance among treatments was tested using one-way or two-way analysis of variance (ANOVA, Tukey's post-hoc test) test for differences using the SPSS 19.0. The significant level was set at 0.05. All data were expressed as the mean \pm standard deviation (SD, $n \geq 3$ ).

\section{Results}

Growth: After being cultured under different $\mathrm{pH}$ levels and $\mathrm{Cu}$ concentrations for $7 \mathrm{~d}$, the growth of $S$. horneri was determined. Results showed that $\mathrm{pH}$ and $\mathrm{Cu}$ exerted a main effect on the RGR, and both had a significant interactive effect as revealed in the two-way ANOVA (Table 1). In addition, the medium $\mathrm{Cu}$ concentration (25 $\left.\mu \mathrm{g} \mathrm{L}^{-1}\right)$ did not affect the RGR significantly, while high $\mathrm{Cu}$ concentration $\left(100 \mu \mathrm{g} \mathrm{L}^{-1}\right)$ significantly reduced the RGR of S. horneri as shown in the post hoc Tukey's comparison (Fig. 2). Moreover, the RGR decreased with the decrease of $\mathrm{pH}$ at all conditions, except at $\mathrm{pH}$ 5.6 and the low $\mathrm{Cu}\left(0 \mu \mathrm{g} \mathrm{L}^{-1}\right)$ in which RGR was $8.3 \%$

Table 1. Results of two-way analysis of variance for the effects of $\mathrm{pH}$ and $\mathrm{Cu}$ on the Sargassum horneri. $\mathrm{pH} \times \mathrm{Cu}-$ the interactive effect between these two factors; $\mathrm{df}$ - degrees of freedom; $F$ - the value of the $F$ statistic.

\begin{tabular}{|c|c|c|c|c|c|c|c|}
\hline Source & $\mathrm{df}$ & $F$ & $P$ value & Source & $\mathrm{df}$ & $F$ & $P$ value \\
\hline RGR & & & & Chl $a$ & & & \\
\hline $\mathrm{pH}$ & 2 & 159.306 & $<0.01$ & $\mathrm{pH}$ & 2 & 0.667 & $>0.05$ \\
\hline $\mathrm{Cu}$ & 2 & 85.319 & $<0.01$ & $\mathrm{Cu}$ & 2 & 16.000 & $<0.01$ \\
\hline $\mathrm{pH} \times \mathrm{Cu}$ & 4 & 17.401 & $<0.01$ & $\mathrm{pH} \times \mathrm{Cu}$ & 4 & 4.434 & $<0.05$ \\
\hline Car & & & & $\mathrm{F}_{\mathrm{v}} / \mathrm{F}_{\mathrm{m}}$ & & & \\
\hline $\mathrm{pH}$ & 2 & 12.488 & $<0.01$ & $\mathrm{pH}$ & 2 & 39.471 & $<0.01$ \\
\hline $\mathrm{Cu}$ & 2 & 37.727 & $<0.01$ & $\mathrm{Cu}$ & 2 & 2.983 & $>0.05$ \\
\hline $\mathrm{pH} \times \mathrm{Cu}$ & 4 & 8.396 & $<0.01$ & $\mathrm{pH} \times \mathrm{Cu}$ & 4 & 0.870 & $>0.05$ \\
\hline $\mathrm{Y}_{\text {(II) }}$ & & & & NPQ & & & \\
\hline $\mathrm{pH}$ & 2 & 22.317 & $<0.01$ & $\mathrm{pH}$ & 2 & 103.892 & $<0.01$ \\
\hline $\mathrm{Cu}$ & 2 & 18.875 & $<0.01$ & $\mathrm{Cu}$ & 2 & 22.523 & $<0.01$ \\
\hline $\mathrm{pH} \times \mathrm{Cu}$ & 4 & 3.489 & $<0.05$ & $\mathrm{pH} \times \mathrm{Cu}$ & 4 & 21.721 & $<0.01$ \\
\hline $\mathrm{Y}_{(\mathrm{NO})}$ & & & & $\mathrm{Y}_{(\mathrm{NPQ})}$ & & & \\
\hline $\mathrm{pH}$ & 2 & 44.477 & $<0.01$ & $\mathrm{pH}$ & 2 & 26.386 & $<0.01$ \\
\hline $\mathrm{Cu}$ & 2 & 0.511 & $>0.05$ & $\mathrm{Cu}$ & 2 & 2.367 & $>0.05$ \\
\hline $\mathrm{pH} \times \mathrm{Cu}$ & 4 & 1.980 & $>0.05$ & $\mathrm{pH} \times \mathrm{Cu}$ & 4 & 3.085 & $<0.05$ \\
\hline$\alpha$ & & & & $\mathrm{rETR}_{\max }$ & & & \\
\hline $\mathrm{pH}$ & 2 & 49.910 & $<0.01$ & $\mathrm{pH}$ & 2 & 31.790 & $<0.01$ \\
\hline $\mathrm{Cu}$ & 2 & 0.562 & $>0.05$ & $\mathrm{Cu}$ & 2 & 36.823 & $<0.01$ \\
\hline $\mathrm{pH} \times \mathrm{Cu}$ & 4 & 0.795 & $>0.05$ & $\mathrm{pH} \times \mathrm{Cu}$ & 4 & 4.220 & $<0.05$ \\
\hline \multicolumn{8}{|l|}{$I_{\mathrm{k}}$} \\
\hline $\mathrm{pH}$ & 2 & 11.878 & $<0.01$ & & & & \\
\hline $\mathrm{Cu}$ & 2 & 18.450 & $<0.01$ & & & & \\
\hline $\mathrm{pH} \times \mathrm{Cu}$ & 4 & 4.494 & $<0.01$ & & & & \\
\hline
\end{tabular}


higher than that of $\mathrm{pH} 8.2$ group. The RGR at $\mathrm{pH} 4.5$ was significantly lower than those at $\mathrm{pH} 5.6$ and 8.2. However, no significant difference was found between $\mathrm{pH} 5.6$ and 8.2 .

Chl $\boldsymbol{a}$ and Car content: As shown in Fig. 3, the decrease in $\mathrm{pH}$ had no negative effects on the contents of $\mathrm{Chl} a$, while higher $\mathrm{Cu}$ concentrations ( 25 and $100 \mu \mathrm{g} \mathrm{L^{-1 }}$ ) reduced significantly the contents of $\mathrm{Chl} a$, except at $\mathrm{pH} 5.6$, at which $\mathrm{Cu}$ had no significant effects on the contents of $\mathrm{Chl} a$. Furthermore, $\mathrm{pH}$ and $\mathrm{Cu}$ showed an interactive effect on the contents of Chl $a$ as indicated in the twoway ANOVA (Table 1). The low $\mathrm{pH}$ worsened the negative effects of $\mathrm{Cu}$ on the contents of $\mathrm{Chl} a$. The lower $\mathrm{pH}$ and higher $\mathrm{Cu}$ concentrations were negatively related to the Car contents. $\mathrm{pH}$ and $\mathrm{Cu}$ were observed as the major influencing factors on the contents of Car as disclosed in two-way ANOVA (Table 1); both showed the significant interactive effect, and low $\mathrm{pH}$ aggravated the decrease of Car caused by excessive $\mathrm{Cu}$.

Chl fluorescence parameters: The $F_{v} / F_{m}$ and NPQ of $S$. horneri under different conditions were measured (Fig. 4). As shown in the two-way ANOVA, $\mathrm{pH}$ exerted a significant effect on $\mathrm{F}_{\mathrm{v}} / \mathrm{F}_{\mathrm{m}}$, but $\mathrm{Cu}$ concentration had no significant effect. Furthermore, $\mathrm{pH}$ had no interactive effect with $\mathrm{Cu}$ concentration (Table 1 ). When the $\mathrm{pH}$ was lowered to $4.5, \mathrm{~F}_{\mathrm{v}} / \mathrm{F}_{\mathrm{m}}$ declined markedly, while higher $\mathrm{pH}$ (5.6 and 8.2) had no significant effects on $\mathrm{F}_{\mathrm{v}} / \mathrm{F}_{\mathrm{m}}$.

In the meantime, $\mathrm{pH}$ showed significant interactive effects with $\mathrm{Cu}$ concentration, and both $\mathrm{pH}$ and $\mathrm{Cu}$ concentration played main effects on NPQ (Table 1). At the seawater $\mathrm{pH} 8.2$, relatively higher $\mathrm{Cu}$ concentration $\left(25 \mu \mathrm{g} \mathrm{L}^{-1}\right)$ induced higher NPQ. With decrease in $\mathrm{pH}$ and increase in $\mathrm{Cu}$ concentration, the NPQ was reduced rapidly, indicating that $\mathrm{pH}$ and $\mathrm{Cu}$ concentration inhibited the photoprotective ability of $S$. horneri.

As shown in Fig. 5, $\mathrm{Y}_{(\mathrm{II})}, \mathrm{Y}_{(\mathrm{NPQ})}$, and $\mathrm{Y}_{(\mathrm{NO})}$ were significantly affected by $\mathrm{pH}$ (Table 1), of which $\mathrm{Y}_{\text {(II) }}$ was also affected by $\mathrm{Cu}$ concentration, and had obvious

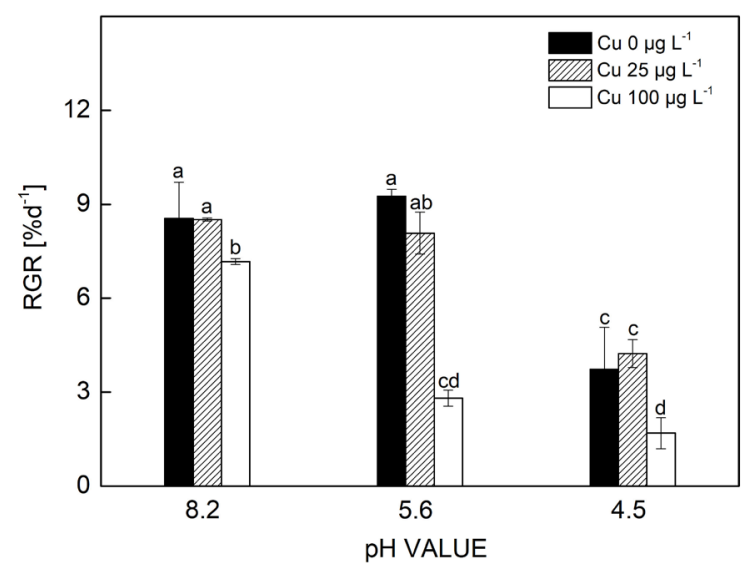

Fig. 2. The relative growth rate (RGR) of Sargassum horneri grown under different treatments for $7 \mathrm{~d}$. Different letters indicate significant differences $(P<0.05)$. interactive effect with $\mathrm{pH}$. $\mathrm{pH}$ promoted the inhibition of $\mathrm{Cu}$ concentration on $\mathrm{Y}_{(\mathrm{II})}$. However, $\mathrm{Cu}$ had no significant effects on $\mathrm{Y}_{(\mathrm{NPQ})}$ and $\mathrm{Y}_{(\mathrm{NO})}$, and had no interaction with $\mathrm{pH}$. As for $\mathrm{Y}_{(\mathrm{NPQ})}$, when $\mathrm{Cu}$ concentration increased to $25 \mu \mathrm{g} \mathrm{L}^{-1}$ at normal $\mathrm{pH}(8.2), \mathrm{Y}_{(\mathrm{NPQ})}$ was higher than that at other treatment conditions, higher $\mathrm{Cu}$ concentration and lower $\mathrm{pH}$ significantly reduced the $\mathrm{Y}_{(\mathrm{NPQ})}$ value. In

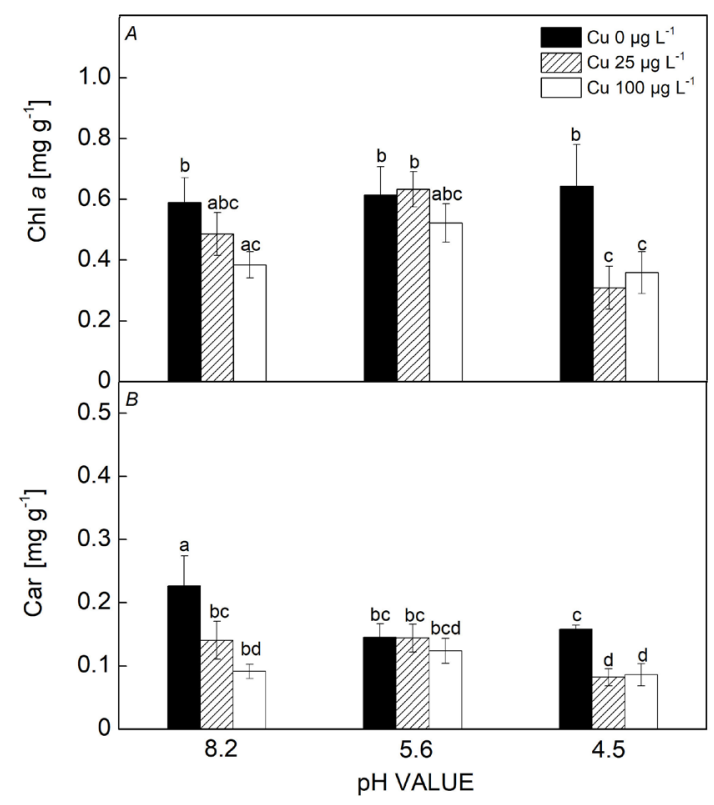

Fig. 3. The chlorophyll (Chl) $a(A)$ and carotenoid (Car) (B) contents of Sargassum horneri grown under different treatments for 7 d. Different letters indicate significant differences $(P<0.05)$.

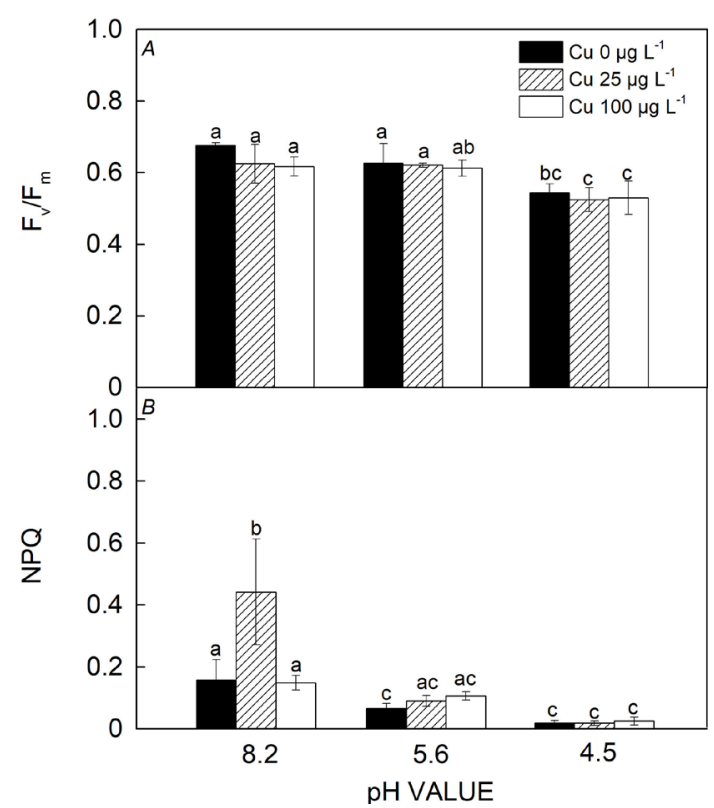

Fig. 4. The maximum PSII quantum yield $\left(\mathrm{F}_{\mathrm{v}} / \mathrm{F}_{\mathrm{m}}\right)(A)$ and nonphotochemical quenching (NPQ) (B) of Sargassum horneri grown under different treatments for $7 \mathrm{~d}$. Different letters indicate significant differences $(P<0.05)$. 
regards to $\mathrm{Y}_{(\mathrm{NO})}$, lower $\mathrm{pH}$ induced higher $\mathrm{Y}_{(\mathrm{NO})}$, while $\mathrm{Cu}$ concentration showed no such a significant effect (Fig. 5).

Effects of light intensity on NPQ of $S$. horneri were changed by $\mathrm{pH}$ and $\mathrm{Cu}$ concentration (Fig. 6). Under normal $\mathrm{pH}$ (8.2) condition, $\mathrm{Cu}$ concentration at $25 \mu \mathrm{g} \mathrm{\textrm {L } ^ { - 1 }}$ induced significantly higher NPQ, while that at $100 \mu \mathrm{g} \mathrm{L} \mathrm{L}^{-1}$ inhibited NPQ, indicating that higher $\mathrm{Cu}$ concentration was harmful to NPQ (Fig. 6A). Additionally, NPQ was sensitive to $\mathrm{pH}$. When the $\mathrm{pH}$ was lower than 8.2, there was no obvious difference between all the treatments, indicating that $\mathrm{pH}$ (5.6 and 4.5) could damage photoprotective ability of S. horneri.

Photosynthetic parameters calculated from the rapid light curve (RLC) of $S$. horneri showed that lower $\mathrm{pH}$ (4.5) significantly inhibited the quantum efficiency of photosynthesis $(\alpha)$, while higher $\mathrm{pH}(\geq 5.6)$ did not (Table 2$)$. As indicated in the two-way $A N O V A, \mathrm{pH}$ affected $\alpha$ obviously, but showed no significant interaction with $\mathrm{Cu}$ concentration (Table 1). Under a given $\mathrm{Cu}$ concentration, lower $\mathrm{pH}$ (5.6 and 4.5) could increase the maximum electron transport rate $\left(\mathrm{rETR}_{\max }\right)$. Higher $\mathrm{pH}$ at 8.2 decreased the $\mathrm{rETR}_{\max }$ with the increase of $\mathrm{Cu}$ concentration, significantly. Besides, when the $\mathrm{pH}$ was 5.6, only the high $\mathrm{Cu}$ concentration $\left(100 \mu \mathrm{g} \mathrm{L}^{-1}\right)$ reduced the $\mathrm{rETR}_{\max }$ significantly, and at low $\mathrm{pH}(4.5), \mathrm{Cu}$ concentration had no significant effects on $\mathrm{rETR}_{\max }$ (Fig. 7, Table 2). Furthermore, $\mathrm{pH}$ and $\mathrm{Cu}$ had clearly an interactive effect on saturating irradiance $\left(I_{\mathrm{k}}\right)$ and both exerted main effects

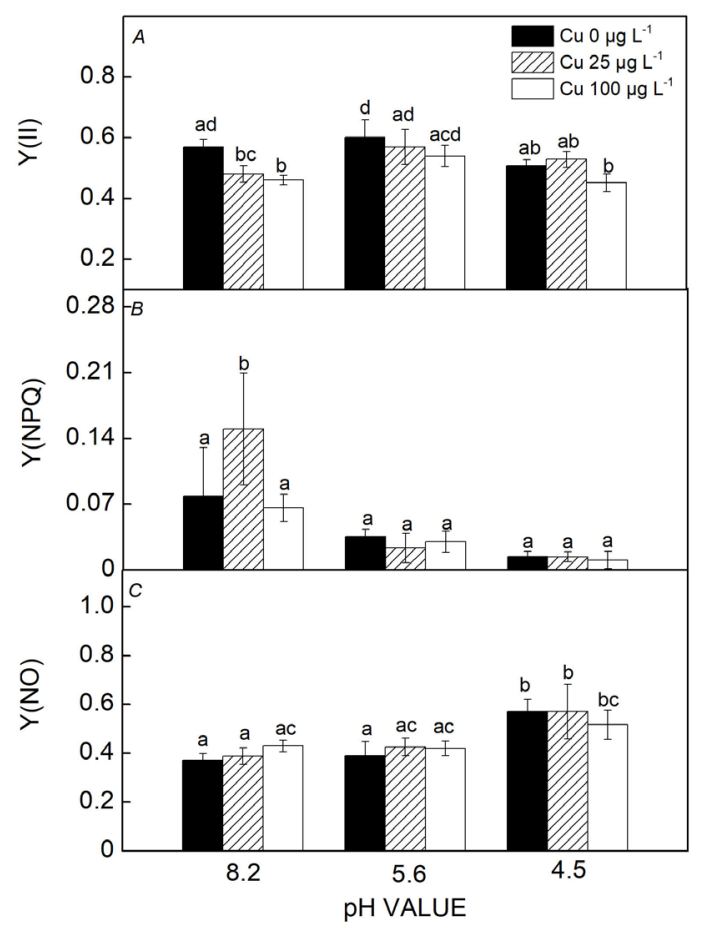

Fig. 5. The actual photochemical efficiency of PSII $\left(\mathrm{Y}_{(\mathrm{II})}\right)(A)$, quantum yield of regulated energy dissipation $\left(\mathrm{Y}_{(\mathrm{NPQ})}\right)(B)$, and quantum yield of nonregulated energy dissipation $\left(\mathrm{Y}_{(\mathrm{NO})}\right)(C)$ of Sargassum horneri grown under different treatments for $7 \mathrm{~d}$. Different letters indicate significant differences $(P<0.05)$.
(Table 1). Except at $\mathrm{pH} 8.2, I_{\mathrm{k}}$ decreased with the increase of $\mathrm{Cu}$ concentration. For example, $I_{\mathrm{k}}$ of the medium $\mathrm{Cu}$ concentration $\left(25 \mu \mathrm{g} \mathrm{L}^{-1}\right)$ was $34.5 \%$ higher than that of the control. Additionally, under a given $\mathrm{Cu}$ concentration condition, low pH (5.6 and 4.5) boosted the $I_{\mathrm{k}}$ value.

\section{Discussion}

Growth: At present, acid rain and copper pollution are widely receiving attentions for their harmful effects to marine ecosystem (Gao et al. 2016, Li et al. 2017, Couet et al. 2018). S. horneri distributes mainly on rocky shores in the intertidal zone (Fig. 1), experiencing daily in and out of seawater. Thus, the chance of meeting acid rain and $\mathrm{Cu}$ pollution is markedly increasing. In this study, we found that the RGR of $S$. horneri was not reduced significantly by medium $\mathrm{Cu}$ concentration $\left(25 \mu \mathrm{g} \mathrm{L}^{-1}\right)$ and $\mathrm{pH}$ (5.6), while the higher $\mathrm{Cu}$ concentration $\left(100 \mu \mathrm{g} \mathrm{L}^{-1}\right)$ or lower $\mathrm{pH}$ (4.5) obviously inhibited the growth unlike low $\mathrm{Cu}$ concentration $\left(0 \mu \mathrm{g} \mathrm{L}^{-1}\right)$ and higher $\mathrm{pH}(8.2)$ did (Fig. 2). The growth performance of algae is an important indicator to the physiological characteristics, and can reflect integrative physiology of the plant. Reportedly, no significant difference was shown in growth rate of Ulva prolifera between $\mathrm{pH} 8.2$ and $\mathrm{pH} 4.4$ (Li et al. 2017). A short-term acid rain could inhibit drastically the photosynthetic properties of Ulva conglobata and even damage the thalli irreversibly under low $\mathrm{pH}$ condition $(\mathrm{pH} 3)$, while the Corallina sp. could survive and regulate the $\mathrm{pH}$ of ambient seawater (Gao et al. 2016). In this study, we showed that $S$. horneri was more sensitive to acid rain compared to Corallina sp. and U. prolifera. Additionally, $\mathrm{Cu}$ is an essential micronutrient for the growth and development of

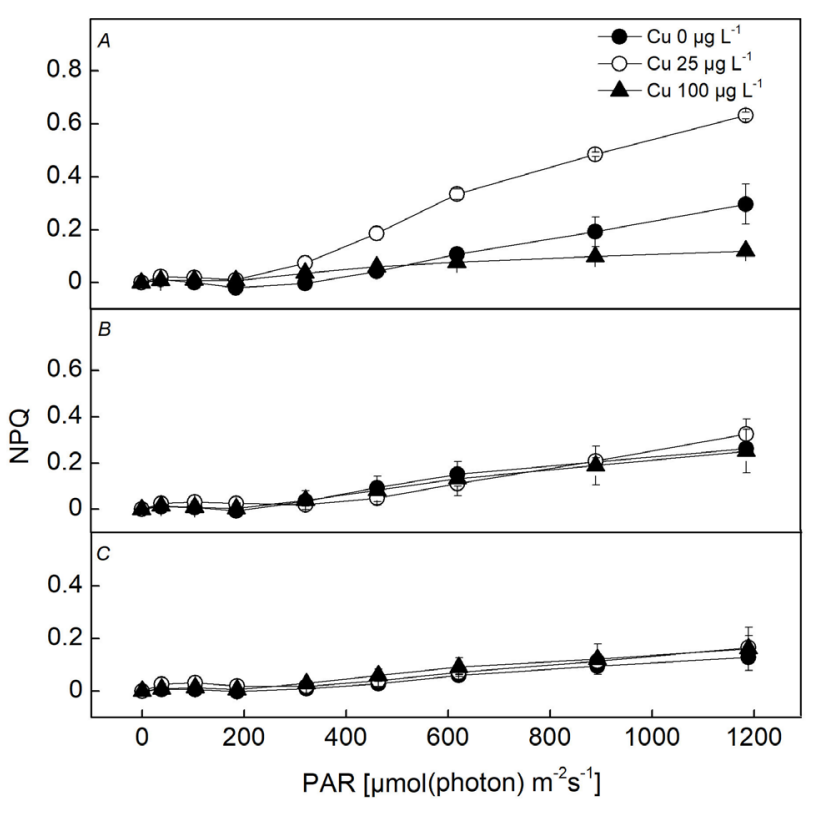

Fig. 6. Effects on nonphotochemical quenching (NPQ) as a function of light intensity of Sargassum horneri grown under different treatments for 7 d. (A) $\mathrm{pH} 8.2$; (B) $\mathrm{pH} 5.6$; (C) $\mathrm{pH} 4.5$. 
Table 2. Photosynthetic parameters calculated from the rapid light curve (RLC) of Sargassum horneri grown under different treatments for 7 d. $\alpha$ - quantum efficiency of photosynthesis; ETR $_{\max }$ - the maximum electron transport rate; $I_{\mathrm{k}}$ - saturated irradiance. Different letters indicate significant differences between different treatments.

\begin{tabular}{lllll}
\hline $\mathrm{pH}$ level & $\mathrm{Cu}$ concentration $\left[\mu \mathrm{g} \mathrm{L}^{-1}\right]$ & $\alpha$ & $\mathrm{rETR}_{\max }$ & $I_{\mathrm{k}}$ \\
\hline 8.2 & 0 & $0.369 \pm 0.013^{\mathrm{a}}$ & $44.21 \pm 1.26^{\mathrm{ad}}$ & $119.51 \pm 6.08^{\mathrm{ac}}$ \\
& 25 & $0.344 \pm 0.021^{\mathrm{a}}$ & $36.52 \pm 2.22^{\mathrm{bd}}$ & $160.73 \pm 33.55^{\mathrm{b}}$ \\
5.6 & 100 & $0.349 \pm 0.019^{\mathrm{a}}$ & $30.34 \pm 0.59^{\mathrm{b}}$ & $84.78 \pm 5.16^{\mathrm{c}}$ \\
& 0 & $0.347 \pm 0.033^{\mathrm{a}}$ & $58.87 \pm 5.15^{\mathrm{c}}$ & $166.78 \pm 34.86^{\mathrm{b}}$ \\
& 25 & $0.344 \pm 0.024^{\mathrm{a}}$ & $51.98 \pm 6.31^{\mathrm{c}}$ & $165.07 \pm 10.45^{\mathrm{b}}$ \\
& 100 & $0.344 \pm 0.034^{\mathrm{a}}$ & $38.46 \pm 2.85^{\mathrm{ad}}$ & $116.43 \pm 9.11^{\mathrm{a}}$ \\
& 0 & $0.267 \pm 0.024^{\mathrm{b}}$ & $45.19 \pm 4.24^{\mathrm{ad}}$ & $168.55 \pm 3.95^{\mathrm{b}}$ \\
& 25 & $0.281 \pm 0.024^{\mathrm{b}}$ & $44.61 \pm 5.86^{\mathrm{a}}$ & $153.76 \pm 17.62^{\mathrm{ab}}$ \\
& 100 & $0.264 \pm 0.032^{\mathrm{b}}$ & $38.82 \pm 3.55^{\mathrm{ad}}$ & $148.03 \pm 13.89^{\mathrm{ab}}$ \\
\hline
\end{tabular}

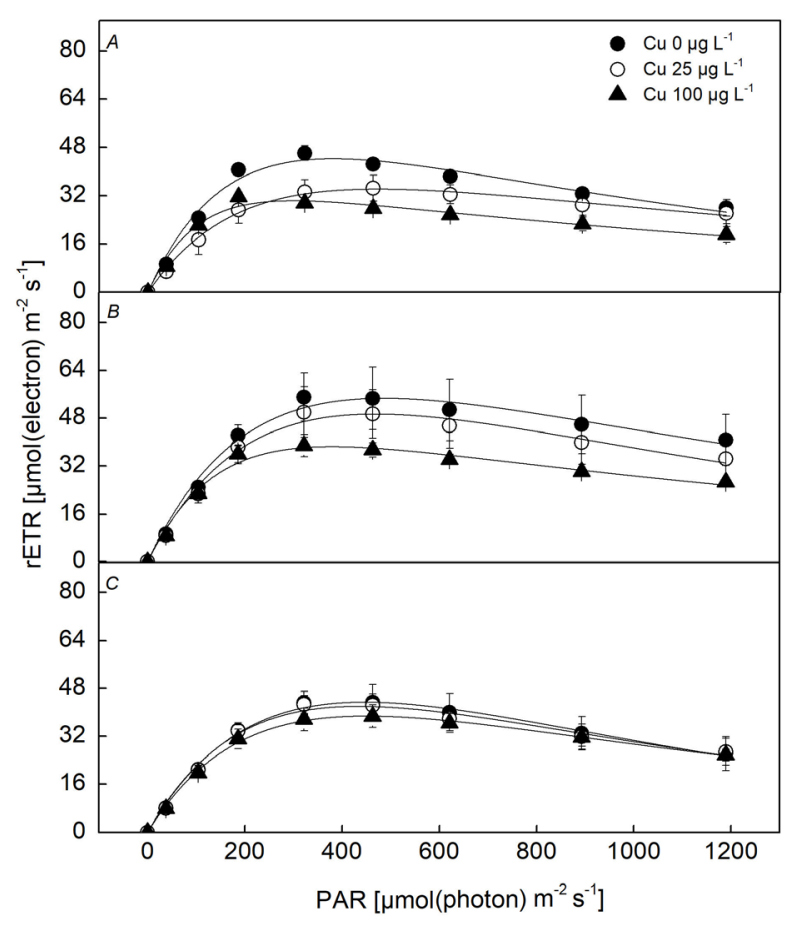

Fig. 7. Rapid light curve (RLC) of Sargassum horneri grown under different treatments for $7 \mathrm{~d}$. $(A) \mathrm{pH} 8.2 ;(B) \mathrm{pH} 5.6 ;(C) \mathrm{pH} 4.5$. rETR - relative electron transfer rate; PAR - photosynthetically active radiation.

macroalgae (Raven et al. 1999). Unfortunately, excessive $\mathrm{Cu}$ would be toxic to the plant (Han et al. 2008), such as $U$. prolifera, for which $0.5 \mu \mathrm{M} \mathrm{Cu}$ inhibited significantly the growth rate (Gao et al. 2017), while the growth of brown macroalga Hizika fusiformis was not reduced significantly at $\mathrm{Cu}$ concentration of $<0.05 \mathrm{mg} \mathrm{L}^{-1}$ (Zhu et al. 2011). Compared to $U$. prolifera and $H$. fusiformis, $S$. horneri is easily affected by $\mathrm{Cu}$ concentration as shown in this study. Nevertheless, Sargassum species have a highly efficient capacity of heavy metal bioaccumulation (Jothinayagi and Anbazhagan 2009). Macroalgae in the intertidal zone can regulate their physiological properties to mitigate the damage from acid rain and $\mathrm{Cu}$ stress, but this adaptive capacity is species dependent, thus more works are needed in the future. As indicated in our twoway $A N O V A, \mathrm{pH}$ had the significant interaction with $\mathrm{Cu}$ concentration on the growth of $S$. horneri, and frequent occurrence of acid rain and $\mathrm{Cu}$ pollution may be one of the causes of Sargassum bed recession.

Photosynthetic performance: Photosynthesis is easily affected by environmental stress. In this study, we showed that $\mathrm{pH}$ exerted a main effect, but $\mathrm{Cu}$ concentration had no significant effect on $F_{v} / F_{m}$ or $\alpha$, and their interaction was not obvious (Table 1). The phenomena indicated that the maximum photochemical quantum yield of PSII and quantum efficiency of photosynthesis were more easily affected by $\mathrm{pH}$ than by $\mathrm{Cu}$ concentration. The low $\mathrm{pH}$ induced by acid rain could disturb the acidity of the cell surface and influence the membrane electrochemical potential and enzyme activities, while algae need to allocate more energy to transport ions against the acidbase perturbation, leading to decreased photosynthetic performance and growth (Milligan et al. 2009, Flynn et al. 2012, Liu et al. 2014, Gao et al. 2019). It has been reported that acid rain had an adverse effect on photosynthesis of $U$. prolifera (Li et al. 2017), and the biodiversity of macroalgae and community structure could be altered by acid rain (Gao et al. 2016). Furthermore, $\mathrm{Y}_{(\mathrm{II})}, \mathrm{rETR}_{\max }$, and $I_{\mathrm{k}}$ were obviously affected by $\mathrm{pH}$ and $\mathrm{Cu}$, and the interactive effects were significant (Table 1). In addition, as shown in Fig. 3 and Table 1, the pH significantly affected the Chl a content of $S$. horneri, and had an interactive effect with $\mathrm{Cu}$. The reasons might be that low $\mathrm{pH}$ could increase the concentration of free $\mathrm{Cu}^{2+}$ in the natural seawater and the excessive $\mathrm{Cu}$ ions could induce the loss of $\mathrm{K}^{+}$and inhibit the uptake of essential nutrient elements by increasing the permeability of the plasma membrane (Lidon and Henriques 1993, Millero 2009). At pH 5.7, the free hydrated $\mathrm{Cu}^{2+}$ was about $98 \%$ of total $\mathrm{Cu}$ with only $1.6 \%$ from $\mathrm{CuOH}^{+}$(Gao et al. 2014). The toxicity of metal pollution is mainly caused by the free hydrated metal ion, rather than total metal concentration (Campbell 1995). Roy-Arcand et al. (1989) pointed out that acid 
rain and metal treatment could cause the main changes in ultrastructure of algal cells, especially the chloroplasts and mitochondria. Tarhanen (1998) also found that the thylakoid and mitochondrial cristae located in chloroplasts and mitochondria, respectively, were swollen that was caused by acid rain and a mixture of copper and nickel. Besides, the Chl $a$ content of $U$. prolifera was significantly reduced by low $\mathrm{pH}$ ( $\mathrm{Li}$ et al. 2017). However, Costa et al. (2016) found that $\mathrm{Cu}$ had positive influence on photosynthetic pigments of Sargassum cymosum, which is contrary to the results of the present study. The photosynthetic pigment contents could be related to the metabolic biosynthesis of antioxidant compounds, the decrease of photosynthetic pigments contents caused by $\mathrm{Cu}$ were the consequence of reduced biosynthesis of enzymes and chloroplasts (Santos et al. 2012). In the present study, we found that medium $\mathrm{pH}$ at 5.6 could mitigate the harm of excessive $\mathrm{Cu}$ (Fig. 3), implying that on the cell surface the competition between $\mathrm{H}^{+}$and $\mathrm{Cu}^{2+}$ exceeded the increased availability of $\mathrm{Cu}^{2+}$ induced by reduced $\mathrm{pH}$ in $S$. horneri (Franklin et al. 2000, Gao et al. 2017). The degradation of $\mathrm{Chl} a$ caused by lower $\mathrm{pH}$ and higher contents of $\mathrm{Cu}$ may be one of the causes of inhibition of photosynthesis.

Photoprotective abilities: The photosynthetic apparatus is the most sensitive to environmental stress (Berry and Björkman 1980), and low pH or higher $\mathrm{Cu}$ concentration can cause imbalance between absorption and utilization of light energy, resulting in inhibition of photosynthesis and damage of PSII by producing active oxygen species (AOS) (Wilson et al. 2006). In order to avoid the photodamage, excess absorbed light can be dissipated through nonphotochemical quenching (NPQ). Under normal conditions, $\mathrm{Y}_{(\mathrm{II})}+\mathrm{Y}_{(\mathrm{NPQ})}+\mathrm{Y}_{(\mathrm{NO})}=1$. In the equation, $\mathrm{Y}_{(\mathrm{II})}$ is the effective PSII quantum yield, representing that absorbed quanta are converted into chemically fixed energy; $\mathrm{Y}_{(\mathrm{NPQ})}$ is the quantum yield for dissipation by downregulation. A high $\mathrm{Y}_{(\mathrm{NPQ})}$ value means that the plant can protect itself from photon flux density by regulation; while a high $\mathrm{Y}_{(\mathrm{NO})}$ indicates that the plant has already been photodamaged (Wang et al. 2009). The present study showed that $\mathrm{pH}$ and $\mathrm{Cu}$ could damage the photoprotective mechanism system. As shown in Fig. 4, Cu concentrations at $25 \mu \mathrm{g} \mathrm{L} \mathrm{L}^{-1}$ significantly induced $\mathrm{NPQ}$ and $\mathrm{Y}_{(\mathrm{NPQ})}$ at $\mathrm{pH} 8.2$, indicating that the medium $\mathrm{Cu}$ concentration caused a stress to $S$. horneri, and more importantly, $S$. horneri could protect itself from photodamage by dissipating excessive excitation energy. In order to defense against the stress of heavy metals, macroalgae have evolved a series of protective mechanisms (Mata et al. 2009, Gao et al. 2017), including cell wall exclusion of metal ions, and chelate with intracellular phytochelatins or polyphosphate (Knauer et al. 1997, Franklin et al. 2000). However, with the increase of $\mathrm{Cu}$ concentration and decrease of $\mathrm{pH}, \mathrm{NPQ}$ and $\mathrm{Y}_{(\mathrm{NPQ})}$ dropped sharply, while $\mathrm{Y}_{(\mathrm{NO})}$ increased. The reason might be that the photoprotective mechanism had been damaged by the $\mathrm{Cu}$ and $\mathrm{pH}$. Gao et al. (2017) also reported that the protective mechanisms had been beaten by excess $\mathrm{Cu}$ $(2 \mu \mathrm{M})$, accompanied by declined growth, rETR, and net photosynthetic rate, which is in accordance with the results of this study (Figs. 2, 4, 7). The negative effect of $\mathrm{Cu}$ on the photoprotective mechanism was magnified under low $\mathrm{pH}$ condition, as depicted in Fig. 5. The reasons might be that low $\mathrm{pH}$ aggravated the acid-base perturbation around the cell surface, and induced more free $\mathrm{Cu}^{2+}$ ions in the culture (Franklin et al. 2000), resulting in more vulnerable cells to $\mathrm{pH}$ and $\mathrm{Cu}$ (Gao et al. 2017). Our study demonstrated that the extent of effects of $\mathrm{pH}$ and $\mathrm{Cu}$ on $S$. horneri was dosage dependent: under the medium concentration of $\mathrm{Cu}$ $\left(25 \mu \mathrm{g} \mathrm{L}^{-1}\right)$, moderate decrease of $\mathrm{pH}$ (5.6) could mitigate the toxicity of $\mathrm{Cu}$, while lower $\mathrm{pH}(4.5)$ aggravated the toxicity of $\mathrm{Cu}$ at high $\mathrm{Cu}$ concentration $\left(100 \mu \mathrm{g} \mathrm{\textrm {L } ^ { - 1 }}\right)$. Similar finding was reported by Gao et al. (2017).

Conclusions: The present study showed that simulated acid rain and $\mathrm{Cu}$ had synergistic effects on the photosynthetic performance, photoprotective ability, and growth of $S$. horneri. Under the medium concentration of $\mathrm{Cu}$ $\left(25 \mu \mathrm{g} \mathrm{L}^{-1}\right)$, moderate decrease of $\mathrm{pH}$ (5.6) could mitigate the toxicity of $\mathrm{Cu}$, while lower $\mathrm{pH}(4.5)$ aggravated the toxicity of $\mathrm{Cu}$ at high $\mathrm{Cu}$ concentration $\left(100 \mu \mathrm{g} \mathrm{L}^{-1}\right)$ on $S$. horneri. As the global ocean temperature rising, which has been obviously accepted by most of scientists in the world, and increased human activities along costal zones, Sargassum beds have been severely degraded in recent years (Komatsu et al. 2014), we should pay more attention seriously on acid rain and metal pollution in the world, and many further works are demanded.

\section{References}

Belshe E.F., Durako M.J., Blum J.E.: Photosynthetic rapid light curves (RLC) of Thalassia testudinum exhibit diurnal variation. - J. Exp. Mar. Biol. Ecol. 342: 253-268, 2007.

Berry J.A., Björkman O.: Photosynthetic response and adaptation to temperature in higher plants. - Annu. Rev. Plant Biol. 31: 491-543, 1980.

Brown M.T., Newman J.E.: Physiological responses of Gracilariopsis longissima (S.G. Gmelin) Steentoft, L.M. Irvine and Farnham (Rhodophyceae) to sub-lethal copper concentrations. - Aquat. Toxicol. 64: 201-213, 2003.

Campbell P.G.: Interactions between trace metals and aquatic organisms: A critique of the free-ion activity model. - In: Tessier A., Turner D.R. (ed.): Metal Speciation and Bioavailability in Aquatic Systems. Pp. 45-102. Wiley, Chichester 1995.

Costa G.B., de Felix M.R.L., Simioni C. et al.: Effects of copper and lead exposure on the ecophysiology of the brown seaweed Sargassum cymosum. - Protoplasma 253: 111-125, 2016.

Couet D., Pringault O., Bancon-Montigny C. et al.: Effects of copper and butyltin compounds on the growth, photosynthetic activity and toxin production of two HAB dinoflagellates: The planktonic Alexandrium catenella and the benthic Ostreopsis cf. ovata. - Aquat. Toxicol. 196: 154-167, 2018.

Du E., Dong D., Zeng X. et al.: Direct effect of acid rain on leaf chlorophyll content of terrestrial plants in China. - Sci. Total Environ. 605-606: 764-769, 2017.

Eilers P., Peeters J.: A model for the relationship between light intensity and the rate of photosynthesis in phytoplankton. Ecol. Model. 42: 199-215, 1988.

Flemming C., Trevors J.: Copper toxicity and chemistry in the environment: a review. - Water Air Soil Poll. 4: 143-158, 1989.

Flynn K.J., Blackford J.C., Baird M.E. et al.: Changes in $\mathrm{pH}$ at 
the exterior surface of plankton with ocean acidification. Nat. Clim. Change 2: 510-513, 2012.

Franklin N.M., Stauber J.L., Markich S.J., Lim R.P.: pHdependent toxicity of copper and uranium to a tropical freshwater alga (Chlorella sp.). - Aquat. Toxicol. 48: 275289,2000 .

Gao G., Gao Q., Bao M. et al.: Nitrogen availability modulates the effects of ocean acidification on biomass yield and food quality of a marine crop Pyropia yezoensis. - Food Chem. 271: 623-629, 2019

Gao G., Liu Y.M., Li X.S. et al.: Expected $\mathrm{CO}_{2}$ induced ocean acidification modulates copper toxicity in the green tide alga Ulva prolifera. - Environ. Exp. Bot. 135: 63-72, 2017.

Gao S., Sun Q.H., Tao Y.L. et al.: A decline in macroalgae species resulting in the overwhelming prevalence of Corallina species is caused by low $\mathrm{pH}$ seawater induced by short term acid rain. - J. Exp. Mar. Biol. Ecol. 475: 144-153, 2016.

Gao X.L., Zhou F.X., Chen C.-T.A.: Pollution status of the Bohai Sea: An overview of the environmental quality assessment related trace metals. - Environ. Int. 62: 12-30, 2014.

Giordani C., Cecchi S., Zanchi C.: Phytoremediation of soil polluted by nickel using agricultural crops. - Environ. Manage. 36: 675-681, 2005.

Gong Q., Wang L., Dai T.W. et al.: Effects of copper on the growth, antioxidant enzymes and photosynthesis of spinach seedlings. - Ecotox. Environ. Safe. 171: 771-780, 2019.

Han H., Kang S.H., Park J.S. et al.: Physiological responses of Ulva pertusa and U. armoricana to copper exposure. - Aquat. Toxicol. 86: 176-184, 2008

Jin X., Liu F., Wang Y. et al.: Probabilistic ecological risk assessment of copper in Chinese offshore marine environments from 2005 to 2012. - Mar. Pollut. Bull. 94: 96-102, 2015.

Jothinayagi N., Anbazhagan C.: Heavy metal monitoring of Rameswaram Coast by some Sargassum species. - Am.Eurasian J. Agr. Environ. Sci. 4: 73-80, 2009.

Knauer K., Behra R., Sigg L.: Effects of free $\mathrm{Cu}^{2+}$ and $\mathrm{Zn}^{2+}$ ions on growth and metal accumulation in freshwater algae. Environ. Toxicol. Chem. 16: 220-229, 1997.

Komatsu T., Fukuda M., Mikami A. et al.: Possible change in distribution of seaweed, Sargassum horneri, in northeast Asia under A2 scenario of global warming and consequent effect on some fish. - Mar. Pollut. Bull. 85: 317-324, 2014

Li Y.H., Wang D., Xu X.T. et al.: Physiological responses of a green algae (Ulva prolifera) exposed to simulated acid rain and decreased salinity. - Photosynthetica 55: 623-629, 2017.

Lidon F.C., Henriques F.S.: Changes in the contents of the photosynthetic electron carriers, RNAse activity and membrane permeability, triggered by excess copper in rice. Photosynthetica 28: 99-108, 1993.

Liu M.H., Korpelainen H., Dong L.C., Yi L.: Physiological responses of Elaeocarpus glabripetalus seedlings exposed to simulated acid rain and cadmium. - Ecotox. Environ. Safe. 175: 118-127, 2019

Liu T.W., Chen J.A., Wang W.H. et al:: A combined proteomic and transcriptomic analysis on sulfur metabolism pathways of Arabidopsis thaliana under simulated acid rain. - PLoS ONE 9: e90120, 2014.

Lombardi A.T., Maldonado M.T.: The effects of copper on the photosynthetic response of Phaeocystis cordata. - Photosynth. Res. 108: 77-87, 2011.

Ma Y.D., Wang B., Zhang R.M. et al.: Initial simulated acid rain impacts reactive oxygen species metabolism and photosynthetic abilities in Cinnamonum camphora undergoing high temperature. - Ind. Crop. Prod. 135: 352-361, 2019.

Mata Y.N., Blázquez M.L., Ballester A. et al.: Biosorption of cadmium, lead and copper with calcium alginate xerogels and immobilized Fucus vesiculosus. - J. Hazard. Mater. 163: 555562,2009

Miki O., Okumura C., Tuji K., Takami M.: Effects of preservation period of fertilization eggs and high concentrations of nitrogen in nutrient sources on germling growth of Sargassum horneri. - J. Appl. Phycol. 28: 2883-2890, 2016.

Milan M., Matozzo V., Pauletto M. et al.: Can ecological history influence response to pollutants? Transcriptomic analysis of Manila clam collected in different Venice lagoon areas and exposed to heavy metal. - Aquat. Toxicol. 174: 123-133, 2016.

Millero F.J.: Effect of ocean acidification on the speciation of metals in seawater. - Oceanography 22: 72-85, 2009.

Milligan A.J., Mioni C.E., Morel F.M.M.: Response of cell surface $\mathrm{pH}$ to $\mathrm{pCO}_{2}$ and iron limitation in the marine diatom Thalassiosira weissflogii. - Mar. Chem. 114: 31-36, 2009.

Parsons T.R., Strickland J.D.: Discussion of spectrophotometric determination of marine plant pigments with revised equations for ascertaining chlorophylls. - J. Mar. Res. 21: 155-163, 1963.

Porra R.J.: The chequered history of the development and use of simultaneous equations for the accurate determination of chlorophylls $a$ and $b$. - Photosynth. Res. 73: 149-156, 2002.

Raven J.A., Evans M.C.W., Korb R.E.: The role of trace metals in photosynthetic electron transport in $\mathrm{O}_{2}$-evolving organisms. Photosynth. Res. 60: 111-149, 1999.

Rocha G.S., Parrish C.C., Lombardi A.T. et al.: Copper affects biochemical and physiological responses of Selenastrum gracile (Reinsch). - Ecotoxicology 25: 1468-1477, 2016.

Roy-Arcand L., Delisle C.E., Brière F.G.: Effects of simulated acid precipitation on the metabolic activity of Cladina stellaris. - Can. J. Bot. 67: 1796-1802, 1989.

Santos R.W., Schmidt E.C., Martins R.P. et al.: Effects of cadmium on growth, photosynthetic pigments, photosynthetic performance, biochemical parameters and structure of chloroplasts in the agarophyte Gracilaria domingensis (Rhodophyta, Gracilariales). - Am. J. Plant Sci. 3: 1077-1084, 2012.

Shukla J.B., Sundar S., Shivangi, Naresh R.: Modeling and analysis of the acid rain formation due to precipitation and its effect on plant species. - Nat. Resour. Model. 26: 53-65, 2013.

Tarhanen S.: Ultrastructural responses of the lichen Bryoria fuscescens to simulated acid rain and heavy metal deposition. - Ann. Bot.-London 82: 735-746, 1998.

Uji T., Nanaumi D., Kawagoe C. et al.: Factors influencing the induction of adventitious bud and callus in the brown alga Sargassum horneri (Turner) C. Agardh. - J. Appl. Phycol. 28: 2435-2443, 2016.

Wang L.J., Loescher W., Duan W. et al.: Heat acclimation induced acquired heat tolerance and cross adaption in different grape cultivars: relationship to photosynthetic energy partitioning. Funct. Plant Biol. 36: 516-526, 2009.

Wang S.Q., Zhang X.Y., Ma Y.D. et al.: Detecting sulfuric and nitric acid rain stresses on Quercus glauca through hyperspectral responses. - Sensors-Basel 18: 830, 2018.

Wilson K.E., Ivanov A.G., Öquist G. et al:: Energy balance, organellar redox status, and acclimation to environmental stress. - Can. J. Bot. 84: 1355-1370, 2006.

Xu M., Sasa S., Komatsu T.: Sargassum horneri C. Agardh space capacity estimation reveals that thallus surface area varies with wet weight. - PLoS ONE 13: e0199103, 2018.

Xu Z., Gao G., Xu J., Wu H.: Physiological response of a golden tide alga (Sargassum muticum) to the interaction of ocean acidification and phosphorus enrichment. - Biogeosciences 
14: 671-681, 2017.

Zhu X.F., Zou D.H., Du H.: Physiological responses of Hizikia fusiformis to copper and cadmium exposure. - Bot. Mar. 54: 431-439, 2011.
Zou H.X., Pang Q.Y., Zhang A.Q. et al.: Excess copper induced proteomic changes in the marine brown algae Sargassum fusiforme. - Ecotox. Environ. Safe. 111: 271-280, 2015.

(C) The authors. This is an open access article distributed under the terms of the Creative Commons BY-NC-ND Licence. 